DOI https://doi.org/10.32837/app.v0i65.318

УДК 314.15:327.8:303

М. А. Семенкова

ORCID ID: https://orcid.org/0000-0002-4143-5671

викладач кафедри іноземних мов

Національного університету оборони України імені Івана Черняховського

\title{
МІЖНАРОДНІ МІГРАЦЙНІ ПРОЦЕСИ ЯК ІНСТРУМЕНТ ГІБРИДНОГО ВПЛИВУ: СТАН ВИВЧЕННЯ ПРОБЛЕМИ
}

\begin{abstract}
3 кінця XIX ст., коли була опублікована робота Е. Равенштайна «Закони міграції», яка вважається першим науковим дослідженням міграції (Ravenstein, 1885), побачили світ багато наукових праць із різних аспектів міжнародних міграційних процесів. Про те, що питання, пов' язані з міграцією, набувають усе більшої актуальності, свідчить і збільшення кількості наукових журналів у світі, науково-дослідницьких центрів, наукових заходів із питань міграції тощо. Зазначимо грунтовність і багатоаспектність досліджень, проте зауважимо, що постійна зміна особливостей і закономірностей міжнародної міграції, а також економічні, суспільнополітичні зміни, які постійно відбуваються у глобальному середовищі, вимагають від наукового співтовариства, що працює в царині міграційних досліджень, постійного прискіпливого вивчення все нових наукових проблем, пов'язаних із міграцією, які неодмінно постають у процесі суспільного розвитку. Зокрема, однією з таких проблем є проблема можливого зовнішнього керування міграційними процесами з метою подальшого використання їх як інструменту гібридного впливу.

Мета статті - зробити аналіз стану вивчення проблеми використання міграції як інструменту гібридного впливу. Для досягнення мети нам потрібно вирішити такі завдання:

- здійснити класифікацію проаналізованої нами наукової літератури з міжнародної міграції;

- виявити наукові дослідження, у яких би безпосередньо вивчалась проблема використання міграції як інструменту гібридного впливу;

- визначити аспекти проблеми, які залишились поза увагою науковців або потребують дороблення.
\end{abstract}

Велика кількість наукових робіт з міграції робить процес їх розгорнутої класифікації вельми складною справою. Однак, обмежуючись контекстом заявленої нами теми й опрацювавши значний масив літератури з теми, ми пропонуємо в загальному вигляді, який, проте, на нашу думку, є точним і зручним, виділити шість основних груп досліджень: роботи, які містять цілісне розуміння міграції як явища; роботи, які присвячені причинам і чинникам міжнародної міграції; роботи, присвячені типології міграційних процесів; роботи, які вивчають питання міграційної політики; дослідження щодо наслідків міграції для країни походження і країни перебування, а також дослідження особливостей перебігу конкретних міграційних процесів.

Отже, до першої групи ми відносимо дослідження, які по суті є розробленими цілісними теоріями міграції і які пояснюють формування міграційних процесів, особливості міграційної поведінки людей, а також механізми самопідтримання міграції. Це гравітаційні теорії міграції, розроблені С. Стоффером (Stouffer, 1949) і Дж. Зіпфом (Zipf, 1940), теорія дії факторів «притягування - виштовхування» Е. Лі (Lee, 1966), неокласична теорія, прибічниками якої були У. Льюіс (Lewis, 1954), М. Тодаро (Todaro, 1969), Дж. Борхас (Borjas, 1989), синтетична теорія, або теорія міграційних мереж Д. Массея (Massey, 1990) і Р. Коена (Cohen, 1987), теорія мобільного переходу, розроблена В. Зелінським (Zelinsky, 1971) і доповнена Р. Скелдоном (Skeldon, 2012) та Д. де Хаасом (de Haas, 2010), теорія міграційних систем, розроблена М. Критц, Л. Лім і Х. Злотнік (Kritz et al., 1992), теорія транснаціоналізму, запропонована С. Вертовичем (Vertovec, 2004) і дороблена П. Левіт і Н. Глік-Шиллер (Levitt, Glick-Schiller, 2004) тощо. Крім вищезазначених авторів, варто згадати і тих, які вивчали міграцію в контексті досліджень інших дисциплін, але водночас питання міграції були невід'ємним елементом і впліталися в розроблені ними теорії. Це теорія сегментованого ринку праці М. Піоре (Piore, 1979), теорія людського капіталу Т. Шульца (Schultz, 1978) тощо. 
До цієї групи досліджень варто віднести і роботи, які містять критичне осмислення міграційних теорій, зокрема і заперечення їхніх окремих постулатів. Це роботи Р. Скелдона, В. Іонцева, С. Каслза, Х. де Хааса, М. Міллера, І. Івахнюк, Л. Рибаковського, Р. Апплеярда, Дж. Фоссета, С. Пассариса й ін. Крім того, доцільно додати в цю групу і роботи, у яких підтримується або спростовується правильність розроблених теорій за результатами емпіричних досліджень, а саме праці Р. Файні, М. Воглера, Р. Ротте, Е. Меєрса й ін.

До другої групи відносимо дослідження, які пояснюють, чому люди мігрують, причому в цьому зв'язку Л. Рибаковський наполягає на необхідності розглядати не тільки чинники і причини, але й умови міграції (Рыбаковский, 2017, с. 53). Хоча вищезазначені праці $з$ теорій міграції значною мірою присвячені, серед іншого, і причинам міграції, варто вказати на дослідників, які у своїх роботах безпосередньо вивчали причини та рушійні сили міграції. Це Л. Рибаковський, О. Малиновська, Ю. Гуменюк, Т. Заславська, Т. Бауер, К. Циммерман, Дж. Борхас, С. Каслз, Д. Хаяр та ін.

Що стосується типології міграції, то варто зазначити наявність різних критеріїв, які обираються авторами. Серед них такі: тривалість перебування в місті вселення, напрямок, ступінь організації, цілі та причини, відстань, характер кордонів, які перетинаються, регулярність тощо. Отже, класифікації міграції містяться в роботах Ю. Римаренка, О. Піскуна, І. Прибиткової, В. Переведенцева, С. Рязанцева, Н. Гонзалеса, С. Каслза й ін. Питання міграційної політики, а також питання управління міжнародною міграцією і міждержавного управління у сфері міграції вивчали О. Малиновська, О. Воробйова, Б. Гош, О. Загробська, Д. Массей, В. Гурандон, А. Геддес, Х. де Хаас, Х. Ентцингер та ін.

Наступна група досліджень містить найбільшу кількість праць, що пояснюється, по-перше, різноманітністю сфер розвитку держави, які зазнають впливу з боку міграції, по-друге неоднозначністю такого впливу. У цю групу увійшли праці, де вивчався вплив міграції на різні міжнародні системи, коли рух населення трансформує глобальні економічні, соціально-політичні та культурні відносини, а також і на рівні національному, коли міграція впливає на економічне і суспільно-політичне становище держави.

Цю групу досліджень доцільно розглянути більш детально, тому що дослідження міграції як інструменту впливу має базуватись на детальному вивченні впливу міграції як стихійного процесу. Отже, можна навести приклади робіт, де досліджується вплив міграції як загалом, так і на окремі сфери життєдіяльності держави. Так, комплексно дане питання досліджено в роботах С. Каслза, Х. де Хааса, М. Міллера, які, крім того, що мають в арсеналі велику кількість публікацій із питань міграції, є і співавторами фундаментального дослідження «Ера міграції», яке витримало шість видань із 1993 р., кожне видання не тільки містило аналіз поточних міграційних процесів, але і концентрувалось навколо найактуальніших питань міграції на момент його підготовки. Зокрема, останнє видання 2019 р. містить узагальнення матеріалів крізь призму авторського погляду на питання сек'юритизації міграції, формування етнічних спільнот, місце міграції в системі міжнародної взаємодії (Castles et al., 2019). Серед авторів, які всебічно досліджували питання впливу міграції, варто також зазначити Дж. Уго, Дж. Льюіса, П. Мартіна, В. Іонцева, О. Позняка, О. Малиновську, Т. Гнатюк, С. Ньюланд, В. Моісеєнко, А. Золберга, Дж. Холліфілда, Х. Злотнік та ін. Можна додати до цього і авторів, які досліджували питання міграції в рамках девелопментології як науки про розвиток, а саме М. Тодаро, який поєднував питання міграції з урбанізацією і вбачав в міграції наслідок і причину слаборозвиненості країн третього світу (Todaro, 1969), Р. Скелдона, який вивчав питання міграції і розвитку, міграції та бідності, приділяв увагу зв'язку між внутрішньою і міжнародною міграцією (Skeldon, 1997) тощо.

Незважаючи на існування наукових праць, у яких питання впливу міграції досліджено комплексно й узагальнено, варто підкреслити переважну полідисциплінарність досліджень, серед яких протягом тривалого часу панівним залишався економічний підхід. Отже, чималий пласт літератури присвячений саме соціально-економічному впливу міграції, різні аспекти якого висвітлювалися Ч. Кінлебергером, Дж. Бордхасом, К. Джонсом, Т. Хаттоном, Дж. Вілліамсоном, Дж. Холліфілдом, Ф. Ортегою, Дж. Пері, К. Пассарісом, Н. Філліпсом, А. Пеллегріно, М. Вуденом. Варто зауважити, що вплив міграції на економічний розвиток оцінюється 
науковцями неоднозначно, особливо дискусійними є питання економічного становища загалом, соціально-економічної нерівності, ринку праці та переказів мігрантів.

Ще один пласт літератури присвячений впливу міграції на суспільно-політичні процеси. Серед досліджень впливу міжнародної міграції на політику можна виділити ті, що вивчають прямий вплив, коли суб'єкти політики ухвалюють політичні рішення з метою регулювання міграційних процесів, а також питання непрямого впливу, де міграційні процеси, які відображаються в суспільній свідомості у вигляді стереотипів або загальних уявлень, використовуються суб'єктами політики згідно з їхніми політичними цілями й інтересами. Варто згадати праці таких авторів, як: О. Малиновська, Р. Альба, Д. Белл, М. Ліві-Баччі, Р. Баубек, Р. Коен, 3. Лейтон-Хенрі, А. Геддес, А. Мессіна й ін.

Окремо варто виділити праці, де досліджено проблеми впливу змін, які відбуваються внаслідок міграції, на чисельність населення, його віковий склад, а також змін структури населення внаслідок переважання представників певних етнічних і релігійних груп населення, на політичну ситуацію в окремих країнах. Це праці А. Топіліна, Ж. Андалл, Д. Беланже, Н. Ванга, Д. Белла, Н. Глейзера, С. Мустерда, А. Портеса й ін. 3 іншого боку, праці К. Бантинг, В. Кимлика, Й. Фегіна, Р. Айрленда, С. Джопке, Б. Пареха, Е. Васти дозволяють нам ознайомитись із політикою щодо культурної інтеграції мігрантів - представників різних етнічних і релігійних груп у різних країна і в різні періоди часу.

3 метою дослідження впливу міграції на суспільно-політичну сферу на особливу увагу в рамках проблематики статті заслуговує питання значення міграції для безпекового середовища. Варто сказати, що воно потрапило в науковий простір відносно нещодавно, коли міграція вже не вважалась лише внутрішньої справою країн, а безпека стала розумітись у більш широкому сенсі, охоплювати, серед іншого, питання міграції, навколишнього середовища, наркобізнесу тощо. Протягом тривалого періоду зв'язок міграції і безпеки розглядався здебільшого з погляду наслідків збройних конфліктів і зводився до проблеми вимушеної міграції, біженців тощо. Проте контекст зв'язку між міжнародною міграцією і безпекою поступово розширювався, вбираючи в себе демографічний, економічний, соціально-політичний аспекти, а також аспект ідентичності.

Вивчення ж зворотного зв' язку, тобто залежності безпекової ситуації від міграційних процесів, було розпочато М. Вайнером і із часом актуалізувалось. Це питання висвітлено в роботах Д. Біго, Ч. Хіршмана, Р. Иеніссена, Р. Лейкена, М. Тітельбаума, Ф. Адамсона, Р. Бурбо, Р. Дансійгер, Д. Грехема й ін. У 1996 р. А. Дауті та Д. Лешер у статті «Потоки біженців як підстава для міжнародних заходів» навіть обгрунтували необхідність втручання у збройний конфлікт не лише з гуманітарного погляду, але і з міркувань безпеки - щоби попередити переміщення біженців (Dowty, Loescher, 1996, с. 45). Натомість I. Саліхьяном у статті, де він також розглядав біженців як джерело міжнародних конфліктів, зазначалось, що втручання країни у внутрішній конфлікт в іншій державі $з$ метою попередження переміщення до неї потоків біженців само стає чинником мілітаризованого міждержавного конфлікту (Salehyan, 2008).

Після ретельного ознайомлення з літературою з питань міграції і проведеного аналізу іiі можна константувати, що питання причин і чинників міграції, а також механізмів ії самовідтворення, з одного боку, і питання наслідків міграції для розвитку країн, з іншого боку, детально розроблені, як і питання міграційної політики, а також питання типології. Крім праць, у яких вищезазначені питання висвітлені в узагальненому теоретичному вигляді, існує велика кількість таких, де досліджують їх у контексті інших тем. Водночас майже в усіх цих публікаціях міграція постає як процес, який ініціюється і набуває свої кількісні та якісні характеристики завдяки дії об'єктивно існуючих обставин, без додаткового впливу ззовні з боку зацікавлених суб'єктів світової політики. Так само здебільшого розглядається вплив міграції як самостійного процесу, а не як інструменту досягнення цілей суб'єктом політики.

Однак нам вдалося виявити деякі наукові праці, у яких автори досліджують міжнародні міграційні процеси з погляду їх можливого цілеспрямованого використання як засобу політичного впливу. Чи не єдиним науковцем, який у цілісному вигляді розглядав міграцію саме в цьому контексті, $є$ К. Грінхілл, яка у 2010 р. у своїй книзі «Зброя масової міграції», а також у низці статей обгрунтовувала вірогідність цілеспрямованої організації міграційних криз і криз, пов'язаних із 
біженцями, зробила спробу визначити, суб'єкти якого типу зазвичай вдаються до організації таких криз і з якою метою. К. Грінхіл висловила думку про те, що ліберальні демократії є більш уразливими до загроз із боку таких штучно створених криз (Greenhill, 2010, с. 37). Цікавим є і іiі спостереження про розділення внаслідок міграційної кризи суспільства на два табори - тих, хто підтримує мігрантів, і тих, хто виступає проти їх в'їзду у країну, що, у свою чергу, також має політичні наслідки. Аспект політичного використання біженців і шукачів притулку представлений і у статті М. Розенблума й І. Саліх' яна «Міжнародні відносини, внутрішня політика і політика щодо шукачів притулку у США», автори якої вказували, що країни більш схильні давати притулок особам із політично ворожих країн, щоб продемонструвати наявність у цих країнах проблем із дотриманням прав людини, уважаючи надання притулку частиною ідеологічної боротьби на міждержавному рівні (Salehyan, Rosenbloom, 2008). У монографії за редакцією С. Стідмана та Ф. Танера на прикладі ситуації в Камбоджі, Пакистані і Конго (Заїр) показано, що біженці водночас стають об'єктами й інструментами маніпулювання з боку держав і повстанських груп, а мілітаризація таборів біженців є частиною довгострокової стратегії сторін, що воюють (Stedman, Tanner, 2003). Питання використання чинника біженців для досягнення суб'єктами політики власної мети досліджувалось також М. Касьяновою, П. Кралюком, Л. Весельською, Дж. Лешер, Дж. Холліфілдом, М. Тітельбаумом та ін.

$\mathcal{E}$ також низка науковців, для яких міграція не була центральним об'єктом їхніх досліджень, проте деякі з їхніх робіт безпосередньо присвячені тій ролі, яка була відведена міграції як інструменту політики. До таких праць можна віднести, зокрема, статтю А. Празмовської «Польські біженці як військовий потенціал: політичні цілі Польського уряду у засланні» (Prazmowska, 1988), колективну монографію «Косово: міжнародні аспекти кризи» (Гуськова та ін., 1999), монографію Д. Нечитайло «Сучасний радикальний ісламізм. Стратегія і тактика» (Нечитайло, 2011) тощо. Описи окремих ситуацій, де міжнародна міграція була тим чи іншим чином використана суб' єктами політики для досягнення цілей, хоча і не дають нам цілісного уявлення про іï використання у світовій політиці, але підтверджують можливість такого використання.

В Україні міграція перебуває в колі наукових інтересів як окремих науковців, так і цілих наукових колективів. Серед найбільш відомих комплексних робіт із міграції, які побачили світ протягом останніх років, варто виділити національну доповідь «Українське суспільство: міграційний вимір», підготовлену Національним інститутом демографії та соціальних досліджень ім. М.В. Птухи (Міграційний вимір, 2018), а також монографію О. Малиновської «Міграційна політика: глобальний контекст і українські реалії», у якій крім аналізу вітчизняного і міжнародного досвіду управління міграційними процесами висвітлені особливості сучасних світових міграційних процесів, а також приділена увага численним проблемним питанням, пов' язаним із міграцією (Малиновська, 2018).

Отже, можна дійти висновку, що вивчення питання використання міграції як інструменту політики, хоча і привертало увагу вчених, але не тією мірою, на яку воно заслуговує. Самі ж дослідження в основному концентруються навколо проблеми міграційних криз, пов' язаних iз масовим залишенням біженцями зони збройного конфлікту, території екологічної катастрофи тощо. В опрацьованих нами роботах використання суб'єктами біженців у політичних цілях в основному зводилося до того, щоби змусити іншу сторону вдатися до тих чи інших дій, ухвалити політичні рішення, вигідні для суб'єкта, отже, передусім було інструментом політичного тиску.

Водночас залишається маловивченим питання використання міграції в ії широкому розумінні, зокрема ії найпоширенішого виду - трудової як засобу впливу, до якого свідомо вдаються учасники міжнародних відносин. Це може пояснюватись неочевидністю і прихованим характером такого використання. Проте особливості сучасного етапу перебігу міграційних процесів і поява завдяки технологічному розвитку в основному вже у другому десятилітті XXI ст. нових ефективних засобів маніпулювання свідомістю людей свідчать про можливість здійснення такого впливу, отже, і доцільність його дослідження.

Навіть більше, якщо в разі стихійного перебігу міграційних процесів вони піддаються саморегулюванню, а також регулюванню з боку країн, що приймають, і країн походження, то цілеспрямований зовнішній вплив на міжнародну міграцію порушує механізми саморегуляції, 
а також обмежує здійснення країнами регулюючої функції. Це актуалізує необхідність вивчення міжнародної міграції, серед іншого, і з погляду впливу на неї зацікавленого зовнішньополітичного актора, а саме:

- $з$ якою метою і за яких умов може здійснюватись зовнішній вплив на міжнародні міграційні процеси;

- яким чином суб'єкт міжнародних відносин може вплинути на формування міграційних потоків, кількісний і якісний склад мігрантів, вибір ними напрямку їхнього руху тощо;

- яким чином те, як міграційні процеси впливають на стан міжнародних відносин і міжнародної безпеки, а також на розвиток окремих країн і безпеки на національному рівні, залежить від прихованого зовнішнього керування міграцією з боку зацікавленого суб'єкта міжнародної політики;

- яким чином таке зовнішнє керування може бути виявлене, як можна попередити використання актором міграційних процесів, особливо з метою деструктивного впливу.

Отже, опрацювання існуючої літератури з питань міграції змушує нас визнавати, з одного боку, грунтовну розробленість питань причин і наслідків міжнародної міграції, міграційної політики, закономірностей і особливостей світових міграційних процесів, а також численної кількості інших аспектів міграційної політики, а з іншого - те, що міграція в цих дослідженнях постає як цілком стихійний процес. Водночас за усвідомлення можливості зовнішнього керування міграційними процесами та їх використання як інструменту політики ми вважаємо за необхідне враховувати таку можливість під час дослідження різних аспектів міжнародних міграційних процесів, зокрема й перелічених вище.

\section{Лimepamypa:}

Ravenstein E. The laws of migration. Journal of the Statistical Society in London. 1885. № 48(2). P. 185-235.

Stouffer S. Intervening Opportunities : A Theory Relating to Mobility and Distance. American Sociological Review. 1940. № 5(6). P. 845-867.

Zipf G. Human behavior and the principle of the least effort. Massachusetts : Addison-Wensley press, 1949.

Lee E. A theory of migration. Demography. 1966. № 3(1). P. 47-57.

Borjas G. Economic Theory and International Migration. International Migration Review. 1989. № 23(3). P. 457-485.

Lewis W. Economic development with unlimited surplus of labour. Manchester school of economic and social studies. 1954. № 22. P. 139-191.

Todaro M. A model of labour migration and urban unemployment in less-developed countries. American Economic Review. 1969. № 59. P. 138-148.

Massey D. Social structure, Household Strategies and the Cumulative theory of migration. Population Index. 1990. № 56(1). P. 3-26.

Cohen R. The new helots: Migrants in the international division of labour. Aldershot: Avebury, 1987.

Zelinsky W. The Hypothesis of the Mobility Transition. Geographical Review. 1971. № 61(2). P. 219-249.

Skeldon R. Migration transition revisited: Their Continuing Relevance for the development of migration theory. Population, Space and Place. 2012. № 18(2). P. 154-166.

De Haas D. Migration transitions: a theoretical and empirical inquiry into the developmental drivers of international migration. IMI/DEMIG. Working Paper № 32. Oxford : International Migration Institute, 2010. URL: www.imi.ox.ac.uk/publications/working_papers.

Kritz M., Lim L., Zlotnik H. International Migration System : A Global Approach. Oxford : Clarendon Press, 1992. Vertovec S. Migrant transnationalism and modes of transformation. International Migration Review. 2004. № 38(3). P. 970-1001.

Levitt P., Glick-Schiller N. Conceptualizing simultaneity: a transnational social field perspective on society. International Migration Review. 2004. № 38(3). P. 1002-1039.

Piore M. Birds of Passage: migrant labor and industrial societies. Cambridge : Cambridge University Press, 1979. Schultz T. Migration: An economist's view. Human Migration / ed. by W. McNeill, R. Adams. Bloomington : Indiana University Press, 1978. P. 350-359.

Castles S., de Haas H., Miller M. The age of migration: international population movements in the modern world. New York : Palgrave Macmillan, 2019.

Skeldon R. Migration and Development : A Global Perspective. Harlow : Addison Wesley Longman, 1997. Dowty A., Loescher G. Refugee Flows as Grounds for International Action. International Security. 1996. № 21(1). P. 43-71. 
Salehyan I. The externalities of Civil Strife: Refugees as a source of international conflict. American Journal of political science. 2008. № 52(4). P. 787-801.

Greenhill K. Weapons of Mass Migration: Forced Displacement, Coercion, and Foreign Policy. New York : Cornell University Press, 2010.

Salehyan I., Rosenbloom M. International Relations, Domestic Politics, and Asylum Admissions. United States Political Research Quarterly. 2008. № 61(1). P. 104-121.

Stedman S., Tanner F. Refugee Manipulation: War, Politics, and the Abuse of Human Suffering. 2003.

Prazmowska Anita J. Polish refugees as military potential: policy objectives of the Polish government in exile. Refugees in the Age of Total War / C. Anna Bramwell (ed.). London : Unwin Hyman Ltd., 1988. P. 219-232.

Гуськова Е., Смирнова Н. Косово : Международные аспекты кризиса / под ред. Д. Тренина, Е. Степановой. Москва : Московский центр Карнеги, 1999. 309 с.

Нечитайло Д. Современный радикальный исламизм : стратегия и тактика. Москва : Наука, 2011. 461 с. Міграційний вимір : національна доповідь. Київ : Інститут демографії та соціальних досліджень ім. М.В. Птухи НАН України, 2018. 396 с.

Малиновська О. Міграційна політика : глобальний контекст та українські реалії. Київ : НІСД, 2018. 472 с. Рыбаковский Л. Факторы и причины миграции населения, механизм их взаимосвязи. Народонаселение. 2017. № 2. C. 51-61.

\section{References}

Ravenstein E.G. (1885) “The laws of migration”. In Journal of the Statistical Society in London. 48(2): 185-235. Stouffer S.A. (1940) "Intervening Opportunities: A Theory Relating to

Mobility and Distance". American Sociological Review. 5(6): 845-867.

Zipf G.K. (1949) Human behavior and the principle of the least effort. Massachusetts: Addison-Wensley press. Lee E.S. (1966) “A theory of migration”. Demography. 3(1): 47-57.

Borjas G.J. (1989) “Economic Theory and International Migration". International Migration Review. 23(3): 457-485.

Lewis W.A. (1954) "Economic development with unlimited surplus of labour". Manchester school of economic and social studies. 22:139-191.

Todaro M.P. (1969) "A model of labour migration and urban unemployment in less-developed countries". American Economic Review. 59:138-148.

Massey D.S. (1990) "Social structure, Household Strategies and the Cumulative theory of migration". Population Index. 56(1): 3-26.

Cohen R. (1987) The new helots: Migrants in the international division of labour Aldershot: Avebury.

Zelinsky W. (1971) “The Hypothesis of the Mobility Transition”. Geographical Review. 61(2): 219-249.

Skeldon R. (2012) "Migration transition revisited: Their Continuing Relevance for the development of migration theory". Population, Space and Place. 18(2): 154-166.

De Haas, D. (2010) Migration transitions: a theoretical and empirical inquiry into the developmental drivers of international migration. IMI/DEMIG Working Paper № 32 Oxford: International Migration Institute. www.imi.ox.ac.uk/publications/working_papers .

Kritz M.M., Lim L.L., Zlotnik H. (1992) International Migration System: A Global Approach. Oxford: Clarendon Press.

Vertovec, S. (2004) "Migrant transnationalism and modes of transformation", International Migration Review. 38(3): 970-1001.

Levitt P., Glick-Schiller N. (2004) “Conceptualizing simultaneity: a transnational social field perspective on society". International Migration Review, 38(3): 1002-1039.

Piore M.J. (1979) Birds of Passage: migrant labor and industrial societies. Cambridge: Cambridge University Press.

Schultz T.W. (1978) “Migration: An economist's view”. In Human Migration ed. by W. McNeill and R. Adams. Bloomington: Indiana University Press: 350-359.

Castles S., de Haas H., Miller M.J. (2019) The age of migration: international population movements in the modern world. New York: Palgrave Macmillan.

Skeldon R. (1997) Migration and Development: A Global Perspective. Harlow: Addison Wesley Longman.

Dowty A., Loescher G. (1996) “Refugee Flows as Grounds for International Action”. International Security. 21(1): 43-71.

Salehyan I., (2008) "The externalities of Civil Strife: Refugees as a source of international conflict". American Journal of political science. 52(4): 787-801. 
Greenhill K.M. (2010) Weapons of Mass Migration: ForcedDisplacement, Coercion, and Foreign Policy. New York: Cornell University Press.

Salehyan I., Rosenbloom M. (2008) "International Relations, Domestic Politics, and Asylum Admissions". United States Political Research Quarterly. 61(1): 104-121.

Stedman S., Tanner F. (2003) Refugee Manipulation: War, Politics, and the Abuse of Human Suffering.

Prazmowska, Anita J. (1988) Polish refugees as military potential: policy objectives of the Polish government in exile. In: Bramwell, Anna C., (ed.) Refugees in the Age of Total War. London: Unwin Hyman Ltd.: 219-232. Guskova E., Smirnova N. (1999) Kosovo: Mezhdunarodnyje aspect crizisa (pod red. D. Trenina, E. Stepanovoj). Moskva: Moskovskij Tsentr Karnegi.

Nechytajlo D.A. (2011) Sovremennyj radikalnyi islamism: strategija i taktika. Moskva: Nauka.

Migratsijnyi vymir: nats. dopovid. (2018) Kyiv: Instytut demographiji ta sotsialnykh doslidzhen im. M.V.Ptukhy NAN Ukrajiny.

Malynovska O.A. (2018) Migratsijna polityka: globalnyj kontekst ta ukrajinski realii. Kyiv: NISD.

Rybakovskij L. (2017) Faktory I prichiny migratsii naselenija, mekhanismy ikh vzaimosvjazi. Narodonaselenije. № 2: 51-61.

\section{Анотачія}

Семенкова М. А. Міжнародні міграційні процеси як інструмент гібридного впливу: стан вивчення проблеми. - Стаття.

У статті проведено аналіз літератури з питань міграції в контексті проблеми ії можливого використання як інструменту гібридного впливу. Здійснено класифікацію наукової літератури з теми, виділено шість основних груп наукових робіт, а саме: загальнотеоретичні дослідження міграції; роботи, у яких вивчаються причини, фактори й умови міграції; роботи, присвячені типології міграційних процесів; дослідження з питань міграційної політики; дослідження щодо наслідків міграції для країни походження і країни перебування; а також роботи, у яких досліджуються конкретні міграційні процеси. Окремі підгрупи літератури виділені серед праць, присвячених впливу міграції на різні аспекти життедіяльності країн походження і країн спрямування мігрантів, що було пояснено як різноманітністю такого впливу, так і його неоднозначністю та дискусійним характером. Окрему увагу в рамках проблематики статті приділено роботам, автори яких вивчають питання зв'язку міграції і безпеки. Зазначено, що майже в усіх роботах міграція досліджується як стихійний процес, наведено лише окремі наукові роботи, де міграція постає як процес ініційований і керований зацікавленим суб'єктом зовнішньої політики, а також вказано на те, що питання керування міграційними процесами з метою досягнення суб'єктами зовнішньополітичних цілей поки залишається маловивченим. У зв' язку із важливістю врахування аспекту цілеспрямованого використання міграційних процесів під час розроблення і впровадженні політики у сфері безпеки обгрунтовано необхідність дослідження міграції з погляду цілеспрямованого і зазвичай прихованого впливу на неї з боку зацікавленого актора. У цьому контексті визначено напрями досліджень міграційних процесів, які натепер не привернули достатньої уваги з боку науковців, але набувають все більшої актуальності, зокрема: за яких умов вони можуть ставати об'єктом зовнішнього впливу; як саме може здійснюватись вплив на їхні особливості і перебіг; яким чином змінені внаслідок зовнішнього впливу міграційні процеси впливають на стан міжнародних відносин і міжнародну безпеку, яким чином такий вплив може бути виявлений.

Ключові слова: міжнародні міграційні процеси, гібридний вплив, стихійна міграція, керована міграція.

\section{Summary}

Semenkova M. A. International migration processes as a tool of the hybrid influence: the state of theme research. - Article.

The article examines the literature on migration in the framework of its possible use as a tool of hybrid influence. The scientific literature was divided into six principal groups: the scientific works that contain the theories of migration; the studies on the causes, factors and the preconditions of migration, the studies on the typology of the migration processes, the studies on the migration policy issues, the studies on the consequences of migration for the country of migrants' origin and the host country and the scientific works that investigate the selected migration processes. Among the scientific works on the influence of migration on the countries of origin and the host countries the author identified several subgroups. It was substantiated by the variability of such influence as well as by the ambiguity and debating nature of the above-mentioned influence. Article gives the specific consideration to the literature on the migration-security nexus. It underlines that migration as a rule is studied as a spontaneous process and only a small number of scientific works deal with migration as with the process initiated and directed by the foreign policy actor. The fact that the aspect of directing the migration processes with the aim to achieve the foreign policy goals needs further research was pointed out in 
the article. Because of the importance of the taking the possibility of use of migration into account during the development and implementation of the migration policy in the sphere of security, the article substantiated the necessity to investigate migration from the point of view of the purposeful but hidden influence on migration by the interested foreign policy actor. In this regard the article defines the areas of the study of international migration processes, that have not been sufficiently addressed by the scholars but at the same time are obtaining the particular significance, such as when and why the migration processes become an object for the external influence; in what way the foreign policy actor can influence migration; how the migration can influence the international relations and international security after being initiated and directed; in what way the external influence on migration can be revealed.

Key words: international migration processes, hybrid influence, spontaneous migration, directed migration. 